\title{
An Easy-to-Use Method for Assessing Nitrate Contamination Susceptibility in Groundwater
}

\author{
Daniela Ducci (i) \\ Department of Civil, Architectural and Environmental Engineering, Università di Napoli Federico II, P.le Tecchio 80, \\ 80125 Naples, Italy \\ Correspondence should be addressed to Daniela Ducci; daniela@unina.it
}

Received 22 November 2017; Revised 24 February 2018; Accepted 10 April 2018; Published 15 May 2018

Academic Editor: Cinzia Federico

Copyright (C) 2018 Daniela Ducci. This is an open access article distributed under the Creative Commons Attribution License, which permits unrestricted use, distribution, and reproduction in any medium, provided the original work is properly cited.

\begin{abstract}
This research presents a methodology for assessing nitrate contamination susceptibility in groundwater using thematic maps, derived mainly from the land use map and from statistical data available at national/regional institutes of statistics (especially demographic and environmental data). The methodology was applied in a large area of southern Italy encompassing 4 alluvial and volcanic groundwater bodies, with high concentrations of $\mathrm{NO}_{3}$. The Potential Nitrate Contamination is believed to derive from three sources: agricultural, urban, and periurban. The first one is related to the use of fertilizers. For this reason the land use map was reclassified on the basis of the crop requirements in terms of fertilizers to obtain the Agricultural Potential Nitrate Contamination (APNC) map. The urban source considers leakages from the sewage network and, consequently, it depends on the anthropogenic pressure, expressed by the population density, particularly concentrated in the urbanized areas (Urban Potential Nitrate Contamination (UPNC) map). The periurban sources include unsewered areas, especially present in the periurban context, where illegal sewage connections coexist with on-site sewage disposal (cesspools, septic tanks, and pit latrines) (Periurban Potential Nitrate Contamination (PuPNC) map). The Potential Nitrate Contamination (PNC) map is produced by overlaying the APNC, UPNC, and PuPNC maps. The map combination process is straightforward, being an algebraic combination: the output values are the arithmetic average of the input values. The final pollution susceptibility (RISK) map is obtained by combining the PNC map with the groundwater contamination vulnerability $(\mathrm{GwVu})$ map. The methodology, successfully applied in the study area with a relatively good correlation between the nitrate contamination susceptibility map and the nitrate distribution in groundwater, appears to be effective and have a significant potential for being applied worldwide.
\end{abstract}

\section{Introduction}

Nitrate groundwater contamination is widespread throughout the world, due to the intensive use of fertilizers, to leaking from the sewage network, and to the presence of old septic systems [1].

Nitrate $\left(\mathrm{NO}_{3}^{-}\right)$is naturally present at varying concentrations in all plants and it is a part of the nitrogen cycle. The main sources of nitrate in groundwater are agricultural activities (including excess application of inorganic nitrogenous fertilizers and manures), wastewater disposals, and oxidized nitrogenous waste products from human and animal excreta, including septic tanks [2]. In humans, high contents of nitrate can cause methaemoglobinaemia, as a consequence of the reaction of nitrite with haemoglobin in the red blood cells to form methaemoglobin, which binds oxygen tightly and does not release it, thus blocking oxygen transport. High levels of methaemoglobin in infants can give rise to cyanosis, referred to as blue-baby syndrome. Therefore, epidemiological evidence for methaemoglobinaemia in infants [3] is the basis for the maximum permissible limit of $50 \mathrm{mg} / \mathrm{l}$ as nitrate in drinking water established by the WHO (World Health Organization) and also recognised by the majority of national drinking water legislations.

Nitrate content in groundwater is increasing on a worldwide scale (Ducci et al. 2017), especially in periurban areas. Rapid population growth and irregular urban development lead to the coexistence of urban, industrial and agricultural/livestock activities, due to the presence of natural areas between urban spaces. In this context, very often 
nitrate groundwater contamination occurs. About $25 \%$ of all groundwater bodies across Europe are in poor chemical status (sensu Water Framework Directive, Directive $2000 / 60 / C E$ ), due to the high concentrations of different chemicals. Often they are nitrate, as a consequence of a range of pressures driven by human activities, especially the application of agricultural fertilizers. If the current trend continues, concentrations of nitrates in water are unlikely to meet good status concentrations within the next 10 to 15 years (EEA 2012).

Likewise, in USA a decadal assessment of trends in concentrations of nitrogen from 1991 to 2003 showed a significant increase of nitrate content in groundwater. Moreover, the nitrate concentrations in deep aquifers are likely to increase during the next decade as shallow groundwater with elevated concentrations moves downward [4].

These findings highlight the strict dependence of nitrate content in groundwater on land use, in terms of agricultural and (or) urban development.

The Methods for Nitrate Groundwater Vulnerability/Risk Assessment. Groundwater vulnerability/risk assessment is an efficient and cost-effective tool of protecting groundwater resources from nitrate contamination at medium/regional scale [5]. In the last thirty years, several models to assess groundwater vulnerability and risk have been developed in order to preserve the quality of groundwater.

Firstly, it is necessary to clarify the concepts of intrinsic and specific vulnerability, hazard, susceptibility, and risk of groundwater contamination.

In the frame of groundwater contamination, the term "vulnerability" or "intrinsic vulnerability" indicates a vulnerability to all contaminants in general and it takes into account the hydrogeological characteristics of the groundwater receptor. There are several groundwater vulnerability assessment models and among these, the parametric DRASTIC model is the most used by the worldwide hydrogeological community.

Systematic and wide reviews of the existing methods to assess groundwater vulnerability are in Kumar et al. [6], Zwalen et al. (2010), and Wachniew et al. [7].

The specific vulnerability is based on the intrinsic vulnerability combined with the properties of a specific contaminant or group of contaminants.

The hazard of groundwater contamination is the overview and the location of the hazards, such as industrial areas and agricultural activities.

The groundwater contamination susceptibility is the combination of the hazard with the vulnerability and generally; due to the difficulty to individuate all the potential contaminant sources and to the presence of a real problem of contamination, the susceptibility is more directed to a specific contaminant.

The groundwater contamination risk also takes into consideration the economic and ecological value of the resource and then adds the "value of groundwater" to the susceptibility. For a hydrogeologist, this concept is very difficult to evaluate, besides being dependent on the scarcity or abundance of groundwater in an area [8-10]. The value can be identified as one or more of the following: groundwater quality, groundwater quantity, groundwater use, ecological value, and costs of remediation of contaminated groundwater.

There is a large literature on the topic of the hazard/risk of groundwater nitrate contamination. Kerr-Upal et al. [11] highlighted the importance of the land use, starting from a study by Baker and Laflen [12]. The study area was too small $\left(200 \mathrm{~km}^{2}\right)$ and the amount of $\mathrm{NO}_{3}$ low (max $19 \mathrm{mg} / \mathrm{L}$ as $\mathrm{NO}_{3}$ ) for considering this method reliable at regional scale. Passarella et al. in [13] applied a disjunctive kriging for estimating the probability of exceeding thresholds (established in 10 and $50 \mathrm{mg} / \mathrm{L}$ ) in an area. The method is based only on the spatial distribution and on the temporal variation of the $\mathrm{NO}_{3}$ content, without considering other parameters. Diodato et al. [14] proposed a nonparametric hydrogeostatistical approach for mapping nitrate hazard in groundwater using the probability kriging (PK) on the basis of the true values of nitrate. Aschonitis et al. [15] developed a set of indices using multiple regression analysis in order to classify the vulnerability of agricultural land to water and nitrogen losses.

A large number of methods derive from the DRASTIC method, modifying the ratings and the weights. Stigter et al. [16] evaluated a Susceptibility Index for diffuse agricultural pollution incorporating the land use in the calculations of the DRASTIC index. The authors think that the results of the application to a small area of Portugal are only partially satisfactory and the method requires further study. Metni et al. [17] assessed the groundwater vulnerability to contamination using DRASTIC at country scale. Huan et al. [18] optimized DRASTIC by rebuilding the index system and adjusting the rating scale of each index on the basis of the correlation coefficient of each index with the nitrate concentration in groundwater. Neshat et al. [19] and Neshat and Pradhan [20] estimated the groundwater vulnerability to pollution using a modified DRASTIC model in an agricultural area of Iran. This method is specific for nitrates and it modifies the DRASTIC rates using the nonparametric Wilcoxon ranksum statistical test. The weights are modified using the sensitivity analysis. In the second paper, the authors also used the Dempster-Shafer theory (DST) to develop a new methodology for assessing pollution risk.

An interesting statistical approach at regional scale is in $[21,22]$. The authors used the weight of evidence method to establish weights and rating of some variables, potentially affecting groundwater vulnerability to nitrate (population density, nitrogen load, soil protective capacity, water table depth, unsaturated hydraulic conductivity, groundwater velocity, and effective infiltration). In the second paper, the authors, keeping the structure of the DRASTIC method, used a spatial statistical approach to calibrate weights and rating of the variables influencing the nitrate vulnerability and verifying the resulting map with the distribution of wells with high nitrate concentration.

A similar approach was proposed by Uhan et al. [23], using as "evidential themes" the long-term groundwater recharge, the nitrogen load in seepage water, and the groundwater flow velocity in the saturated zone. 
Also the indicator kriging technique has been used for the assessment of nitrate contamination in groundwater: examples are in Sheikhy Narany et al. [24] and Chen et al. [25], both starting from DRASTIC, in Piccini et al. [26] and in Chica-Olmo et al. [27], where the authors conclude that multiple indicator kriging is the best technique to estimate probability maps in order to assess the risk of nitrate contamination.

Fijani et al. [28] introduce a supervised committee machine with artificial intelligence (SCMAI) model to improve DRASTIC. The application in a plain in Iran shows that no water well with high $\mathrm{NO}_{3}$ levels is classified as low risk by the SCMAI model, and therefore it is an effective model to improve the DRASTIC method.

Finally, Kumar et al. [5] present an optimization of the DRASTIC parameters, evaluating consistent weights and ratings on the basis of scientific examination of the anthropogenic factors causing groundwater contamination.

The IPNOA method [29] is a parametric index which assesses the potential hazard of nitrate contamination originating from agriculture on a regional scale. The method integrates the hazard (use of fertilizers, application of livestock and poultry manure, food industry wastewater, and urban sludge) and the control factors (geographical location, climatic conditions, and agronomic practices). Finally, the Potential Risk Map is obtained by coupling the potential hazard of nitrate pollution (IPNOA) and the aquifer contamination vulnerability map. This method seems to be very effective [30-32], but since it requires a great deal of data, it is often very difficult to apply, especially in large areas. Moreover, the data collection requires deep scientific knowledge of the problems, not always held by environmental technicians who draw up the maps.

The research reported herein presents a methodology for groundwater contamination susceptibility assessment using thematic maps mainly derived from the land use map and from statistical data available at the national institutes of statistics (especially demographic and environmental data).

The methodology is based on the definition of the factors significant for nitrate contamination in groundwater. These factors have been classified and mapped as GIS layers. The Potential Nitrate Contamination map has been drawn up using a new protocol for overlapping the weighted GIS layers corresponding to the factors of the contamination previously individuated; the method is applied to 4 groundwater bodies of southern Italy, characterized by urban, periurban, and agricultural environments, with, in a wide sector, very high concentrations of $\mathrm{NO}_{3}$.

\section{Study Area}

The study area (about $1800 \mathrm{~km}^{2}$ ) encompasses the prevalently flat areas located north of the town of Naples, between the carbonate mountains to the east and the Tyrrhenian Sea to the west.

The main land use types of the area are agricultural areas (71.3\%) and urbanized and industrial areas (25\%). Indeed, the area is characterized by the coexistence of industrial settlements, urban spaces, and agricultural landscape. This chaotic urbanization creates a large-extent ecological disturbance, especially affecting the aquifers, caused by agriculture and animal-rearing, domestic and industrial wastewater, and solid waste.

The climate over the study area is characterized by cool, rainy autumn, and winter (November to February) and warm, dry summer. The yearly mean temperatures range between $16^{\circ} \mathrm{C}$ and $18^{\circ} \mathrm{C}$ and the yearly mean rainfall ranges from $800 \mathrm{~mm} / \mathrm{y}$ along the coast to a maximum of $1000-1200 \mathrm{~mm} / \mathrm{y}$ at the foot of the mountains.

2.1. Hydrogeological Setting of the Study Area. The area encompasses 4 groundwater bodies (GWBs) of the Campania region, the Garigliano Plain (P-GRGL), the lower portion of the Volturno River (P-VLTR), the eastern Plain of Naples (PNAP), and the Phleagrean Fields (FLE) and it is surrounded by the Mesozoic limestone mountains of the Southern Apennines (E and N), by the extinct Roccamonfina volcano (NE), by the Somma-Vesuvius volcano (S), and by the Tyrrhenian Sea (W and S) (Figure 1).

The P-GAR GWB $\left(137 \mathrm{~km}^{2}\right)$ is a graben filled by clastic deposits, containing in its uppermost part volcanic sediments from the nearby Roccamonfina volcano. Along the coast, old dunes run parallel to the coastline. The aquifer consists of marine and alluvial deposits, interbedded with pyroclastics in its northeast sector. The depth of the water table ranges from 0 (along the coast) to $30 \mathrm{~m} \mathrm{bgl}$, excluding the part at the foot of the Roccamonfina Volcano, where the depth to the water is $80-100 \mathrm{~m}$ bgl. Groundwater flow is directed toward the sea and the Garigliano River [33].

The P-VLTR GWB $\left(1.069 \mathrm{~km}^{2}\right)$ is made up of quaternary alluvial-pyroclastic and pyroclastic porous deposits [37]. Campanian Ignimbrite is a large-volume trachytic tuff which erupted from the Phlegrean Fields (37-39 ka BP) and consisted of a fallout deposit overlain by ignimbrite. Almost everywhere the Campanian Ignimbrite tuffs cross or underlie the above-mentioned alluvial and pyroclastic sediments and overlie Plio-Pleistocene lacustrine, palustrine, and marine deposits. The hydrogeological setting is closely related to the thickness and the physical characteristics (lithification, granulometry, amount of scoria, etc.) of Campanian Ignimbrite, which plays the role of semiconfining or confining bed. In the northern sector, the aquifer is underlain by the Campanian Ignimbrite tuffs and oldest tuffs, and consequently it is prevalently confined. In the southern sector, the aquifer is semiconfined almost everywhere, while in the central part, close to the Volturno River, it is phreatic, because the tuffs are absent or very thin, due to the river erosion. Although it is possible to zone areas with different hydrogeological conditions, the Campanian Plain can be considered a single groundwater body, for the frequent interconnections between the aquifers. The plain includes shallow aquifers constituted by alluvial and pyroclastic deposits overlaying the tuffs (Campanian Ignimbrite). However, the main aquifer is confined or semiconfined and is located in the alluvial, pyroclastic, and marine porous sediments underlying the Campanian Ignimbrite $[30,34]$. The depth of the water table ranges from 0 to $15 \mathrm{~m}$ bgl for the shallow unconfined aquifers and $30-50 \mathrm{~m}$ for the confined/semiconfined deeper aquifers. 

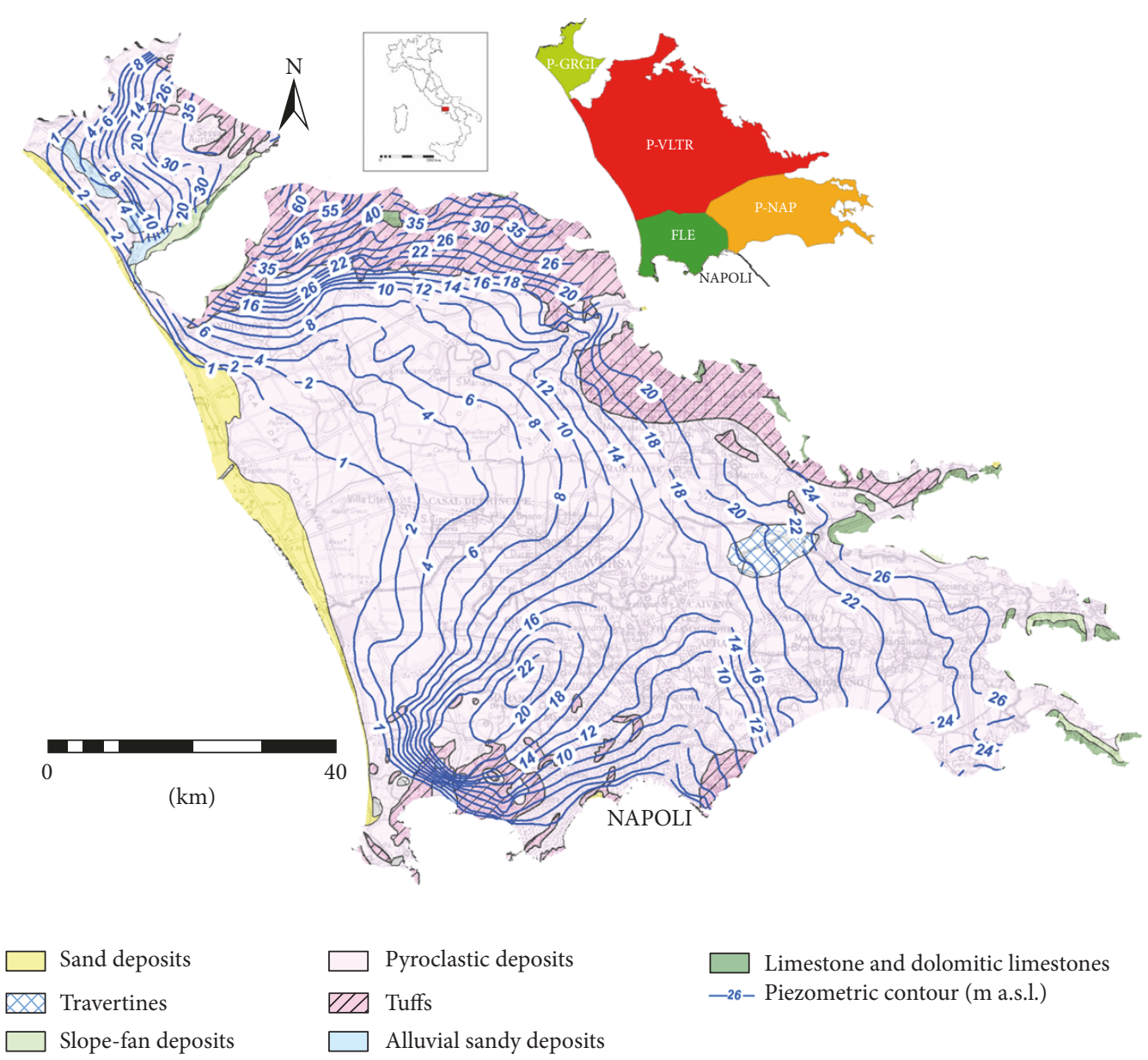

-26- Piezometric contour (m a.s.l.)

FIGURE 1: Location and hydrogeological map of the study area (modified from [33, 34]). On the top the groundwater bodies (GWBs): the Garigliano Plain (P-GRGL), the lower part of the Volturno River Basin (P-VLTR), the eastern Plain of Naples (P-NAP), and the Phleagrean Fields (FLE).

The P-NAP GWB $\left(430 \mathrm{~km}^{2}\right)$ is constituted approximately by the same deposits, but the tuffs are often absent and the aquifer is phreatic or locally confined by peat levels. The groundwater flow is directed east-northeast through southwest. The depth of the water table increases from the coast toward east-northeast, where it exceeds $50 \mathrm{~m} \mathrm{bgl}$.

The aquifer of the FLE GWB $\left(203 \mathrm{~km}^{2}\right)$ is a succession of pyroclastic beds with different grain sizes and cementation degrees. The piezometric surface indicates a radial groundwater flow toward the sea and the P-VLTR. In the central part the water table depth exceeds $100 \mathrm{~m}$ bgl.

The GWBs of the plains (P-GRGL and P-VLTR) receive groundwater inflows from adjacent volcanic (also FLE) and carbonate aquifers. Inflows from the adjacent carbonate massifs produce a clear hydrochemical mark, with large values of $\mathrm{r}(\mathrm{Ca}+\mathrm{Mg}) / \mathrm{r}(\mathrm{Na}+\mathrm{K})$. From the limestone mountains toward the sea, this ion ratio decreases because of alkaline enrichment contained in pyroclastic deposits of the plains. Near the Volturno River mouth, the hydrogeochemistry is influenced by saltwater intrusion.

There are also mineralized areas along the borders of the P-GRGL and P-VLTR plains [34] and in the whole FLE GWB, where there is a complex interaction between deep volcanic fluids, fresh groundwater, and seawater.

In the plains the groundwater contamination, studied on the basis of chemical data from more than 250 wells (Figure 2), is considerable, due to the widespread presence of intensive agriculture and the high population density, especially in the south-eastern part. Many wells show very high nitrate concentrations and in the P-VLTR GWB more than $60 \%$ of the area is above the WHO threshold of $50 \mathrm{mg} / \mathrm{L}$ (also recognised by European Union and Italian drinking water legislation).

\section{The Method for Nitrate Groundwater Susceptibility Assessment}

3.1. The Software Used. In this work multiple GIS software packages were used: ArcGIS 10.2 (ESRI), QGIS 2.14 (Open Source GIS), and ILWIS 3.4 (Open Source GIS). The latter has been used prevalently for the layers overlay analysis and calculation. The final output of the figures has been created using ArcGIS. Excel 2013 has been used for TAB data. 


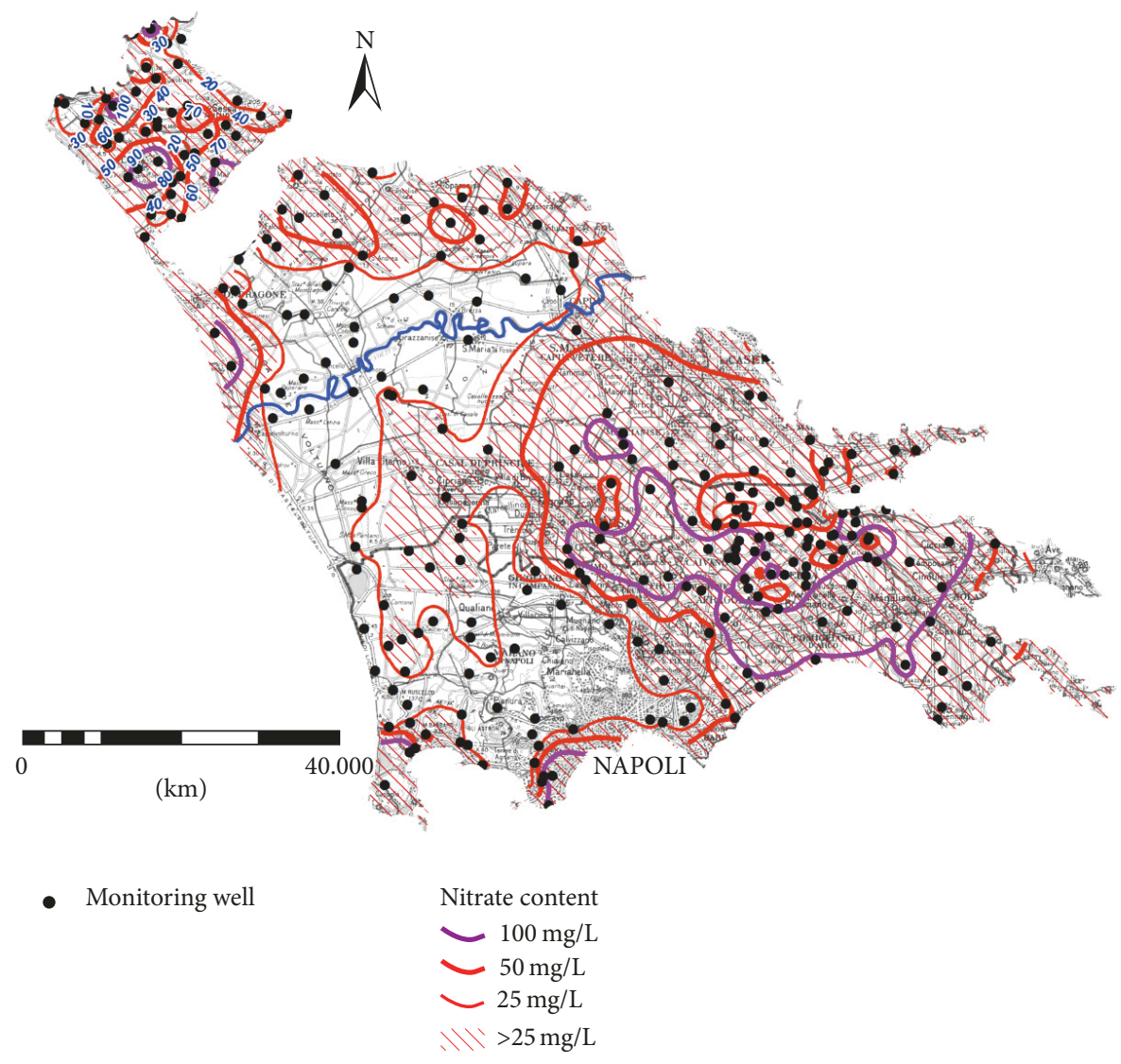

FIGURE 2: Nitrate content (mg/L) in groundwater (modified from $[33,34]$ ) and monitoring wells network.

The coordinates (UTM, WGS84) of the borders of the maps are $X \min =396300 ; X \max =472320 ; Y \min =4514700$; $Y \max =4572500$. All the maps are north-oriented. The majority of the maps have a topographic base extracted from the map of the Campania region at 1:200.000 scale.

3.2. The Proposed Method. The method, partially derived from a previous experience of the author in terms of groundwater risk contamination evaluation and geoindicators [38], uses thematic maps derived mainly from the land use map and from statistical data available at the national institute of statistics (especially demographic and environmental data). In Figure 3 the processes to define the Groundwater Nitrate Contamination Susceptibility (RISK) map are resumed.

The Potential Nitrate Contamination (PNC) is considered as deriving from three sources: agricultural (APNC: Agricultural Potential Nitrate Contamination), urban (UPNC: Urban Potential Nitrate Contamination), and periurban (PuPNC: Periurban Potential Nitrate Contamination).

Since the strict dependence of nitrate content in groundwater on land use, the APNC, related to the use of fertilizers, is derived from the land use map. The land use map used is the Corine Land Cover at level 2 distributed by http://land.copernicus.eu/pan-european/corine-land-cover/clc-2012. The Corine Land Cover crops have been reclassified in APNC (Table 1), depending on the requirements in terms of fertilizers and according to the $\mathrm{N}$ (in $\mathrm{kg} / \mathrm{ha} /$ year) surplus class indicated in Crouzet [39].

The UPNC is the possibility of leaks from the sewage network and, consequently, is linked to the anthropogenic pressure, expressed by the population density. The choice of the classes of population density is derived from a synthesis of different examples (e.g., https://soils.usda.gov/). These data derive principally from national and regional statistical archive data, and they are often aggregate for municipality (in Italy ISTAT, the Italian National Institute of Statistics, produces official statistics available at https://www.istat.it/). On the basis of these data, we can have only a map of the municipalities with a different classification in terms of density. To have a more reliable map of density and less linked to the administrative limits, the urbanized areas have been mapped and classified with a class increased by one, as compared to the municipality, while in the unurbanized areas the density class of the municipality has been decreased by one (Table 2).

The periurban sources, PuPNC, include the unsewered areas, especially present in the periurban context [40], where illegal sewage connections coexist with on-site sewage disposal (cesspools, septic tanks, and pit latrines). The adopted classes are indicated in Table 3.

The Potential Nitrate Contamination (PNC) map is produced by overlaying the agricultural (APNC), urban (UPNC), 
TABle 1: Land use (Corine level 2) classification in the Agricultural Potential Nitrate Contamination.

\begin{tabular}{lcc}
\hline CLC & Corine description & $\begin{array}{c}\text { Agricultural Potential Nitrate } \\
\text { Contamination (APNC) }\end{array}$ \\
\hline 1.1 & Urban fabric & Low \\
1.2 & Industrial, commercial, and transport units & Low \\
1.3 & Mine, dump, and construction sites & Low \\
1.4 & Artificial, nonagric, vegetated areas & Low \\
2.1 & Arable land & Very high \\
2.2 & Permanent crops & High \\
2.3 & Pastures & Moderate \\
2.4 & Heterogeneous agricultural areas & High \\
3.1 & Forests & Very low \\
3.2 & Scrub/herbaceous vegetation association & Very low \\
3.3 & Open spaces with little or no vegetation & Very low \\
4.2 & Maritime coastlands & Low \\
5.1 & Inland waters & Low \\
\hline
\end{tabular}

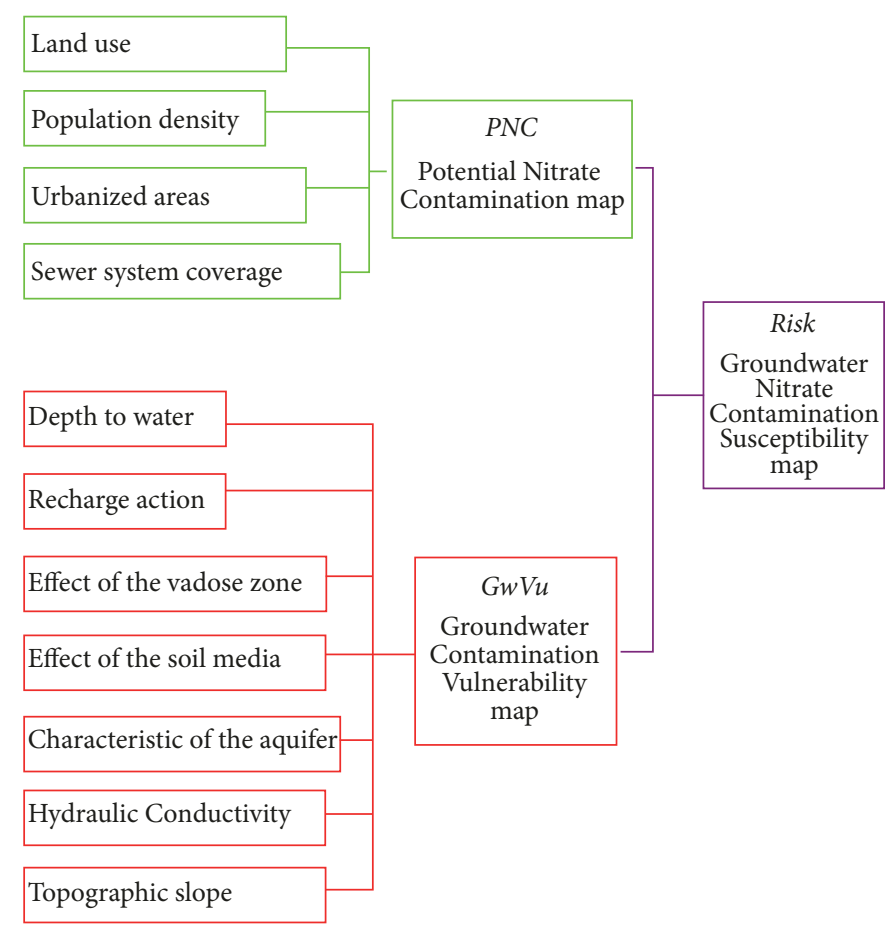

Figure 3: Scheme of work to draw up the Groundwater Nitrate Contamination Susceptibility map.

and periurban (PuPNC) maps. The map combination process here applied is very easy to use (Table 4); it is an algebraic combination or an index overlay combination, considering all maps of equal weight: the resulting values are the arithmetic average of the input values, starting from 1 (very low) to 5 (very high).

As explained in Section 3, in the scientific literature, a large number of vulnerability assessment methods is available. The validity of the vulnerability map strictly depends, more than on the choice of the method, on the accuracy of the parameters estimation procedure. For the susceptibility assessment with the proposed method any contamination vulnerability method can be used (such as DRASTIC); the method merely requires a classification into five classes and in most cases, previous documents produced at regional level can be used.

The final Groundwater Nitrate Contamination Susceptibility (RISK) map is produced by overlapping the Potential Nitrate Contamination (PNC) map and the groundwater contamination vulnerability (GwVu) map. Also for these two maps the easy combination process explained above is applied: the susceptibility values are the arithmetic average of 
TABLE 2: Population density classes and reclassification in the Urban Potential Nitrate Contamination.

\begin{tabular}{lccc}
\hline $\begin{array}{l}\text { Population } \\
\text { density } \\
\text { per km }\end{array}$ & $\begin{array}{c}\text { Urban Potential } \\
\text { Nitrate } \\
\text { Contamination } \\
\text { (UPNC) }\end{array}$ & $\begin{array}{c}\text { UPNC in } \\
\text { urbanized areas }\end{array}$ & $\begin{array}{c}\text { UPNC in } \\
\text { uninhabited } \\
\text { areas }\end{array}$ \\
\hline$<5$ & Very low & Low & Very low \\
$5-25$ & Low & Moderate & Very low \\
$25-250$ & Moderate & High & Low \\
$250-1000$ & High & Very high & Moderate \\
$>1000$ & Very high & Very high & High \\
\hline
\end{tabular}

TABLE 3: Sewer system coverage and reclassification in the Periurban Potential Nitrate Contamination.

\begin{tabular}{lc}
\hline $\begin{array}{l}\text { Sewer system coverage } \\
\%\end{array}$ & $\begin{array}{c}\text { Periurban Potential Nitrate } \\
\text { Contamination (PuPNC) }\end{array}$ \\
\hline$>90$ & Very low \\
$70-90$ & Low \\
$50-70$ & Moderate \\
$25-50$ & High \\
$<25$ & Very high \\
\hline
\end{tabular}

the input values (PNC and GWVu), starting from 1 (very low) to 5 (very high).

\section{Results}

In the study area, the prevailing land uses are arable land $(43 \%)$ and permanent crops $(21 \%)$, followed by heterogeneous agricultural areas (14\%). Almost $20 \%$ of the area is occupied by urban and industrial settlements (Figure 4(a)). This is reflected in the APNC map, showing almost $80 \%$ of the area at high and very high degree of Potential Nitrate Contamination for agriculture (Figure 4(b)).

The study area is densely populated (Figure 4(c)); there are 120 municipalities, with population density ranging between 60 and 12,000 inhabitants $/ \mathrm{km}^{2}$ and half of the municipalities have more than 1,000 inhabitants $/ \mathrm{km}^{2}$, prevalently concentrated in the urbanized areas (17\%). The UPNC map (Figure $4(\mathrm{~d})$ ) shows that more than $50 \%$ of the area is at very high degree of Potential Nitrate Contamination for anthropogenic pressure.

The mean of the sewer coverage in the study area is $85 \%$ : a large number of municipalities are completely covered, but one municipality has less than $25 \%$. The PuPNC map (Figure 5) shows the greater part of the area at low and very low degree of Potential Nitrate Contamination for illegal sewage connections and on-site sewage disposal.

The Potential Nitrate Contamination (PNC) map (Figure 6) derived from agricultural, urban, and periurban sources has been drawn up on the basis of the overlay matrix of Table 4. Two-thirds of the area are at moderate hazard, while one-third is at high hazard for nitrate contamination.
Very small areas are at low and very high hazard (less than $2 \%)$.

In Figure 6 this map is compared with the groundwater contamination vulnerability $(\mathrm{GwVu})$, assessed using previous documents produced using the SINTACS method [36], which uses the same seven parameters as DRASTIC, but the rating and weighting procedure is more flexible. In the case study the layers of previous adjacent maps [34, 35] were merged and reclassified into five classes. The prevalent vulnerability class is moderate (76\%). The Groundwater Nitrate Contamination Susceptibility (RISK) map is shown in Figure 7. Groundwater appears to be at moderate-high susceptibility for nitrate contamination: $60 \%$ of the area is at moderate susceptibility, $39 \%$ is at high susceptibility, and the remaining $1 \%$ is constituted by small areas at low susceptibility.

\section{Discussion}

The final Groundwater Nitrate Contamination Susceptibility map (Figure 7) is very little diversified, showing only two classes of susceptibility: moderate and high. The comparison between the susceptibility map and the map of nitrate distribution (Figure 2) shows a clear agreement between susceptibility degree and nitrate concentration. Indeed, a correlation analysis carried out using the spatial statistic function of the GIS shows the highest correlation (64\%) between medium values of $\mathrm{NO}_{3}(25-50 \mathrm{mg} / \mathrm{L})$ and the moderate susceptibility class and also a good correlation (52\%) between highest values of $\mathrm{NO}_{3}(>50 \mathrm{mg} / \mathrm{L})$ and the high susceptibility class.

Along the Volturno River, the nitrate content is very low (Figure 2), despite a moderate-high susceptibility. This difference can be easily explained because in this area the $\mathrm{SO}_{4}$ content is also low, while $\mathrm{CO}_{2}, \mathrm{Fe}$, and $\mathrm{Mn}$ are high, because there are negative redox conditions in the aquifer [34]. Excluding this area, the correlation between the susceptibility map and the nitrate content in groundwater, calculated using the spatial statistic, increases, as shown in Figure 8.

The generally very useful sensitivity analysis, performed by removing alternatively the various layers from the final susceptibility map [10], would have in this case low significance, involving only the APNC, UPNC, and PuPNC maps, because the original layers of the vulnerability map are not available for the whole area. Nevertheless, it should be highlighted that the spatial analysis shows that the PNC is the most important parameter and the $89 \%$ of the area shows the same classes of the final susceptibility (RISK) map.

Indeed, the susceptibility map reflects the PNC map and his low differentiation; however the vulnerability map is even less diversified, due to the uniformity of the aquifers. An attempt carried out using more susceptibility classes led to only a small improvement in the differentiation.

The good correlation is a satisfactory result for this first application of this method. Future applications in different contexts, from the hydrogeological point of view and of the land use, could confirm the suitability of this method, especially in the possibility of better differentiate areas, facilitating the choices of the decision-makers for the future land use. 


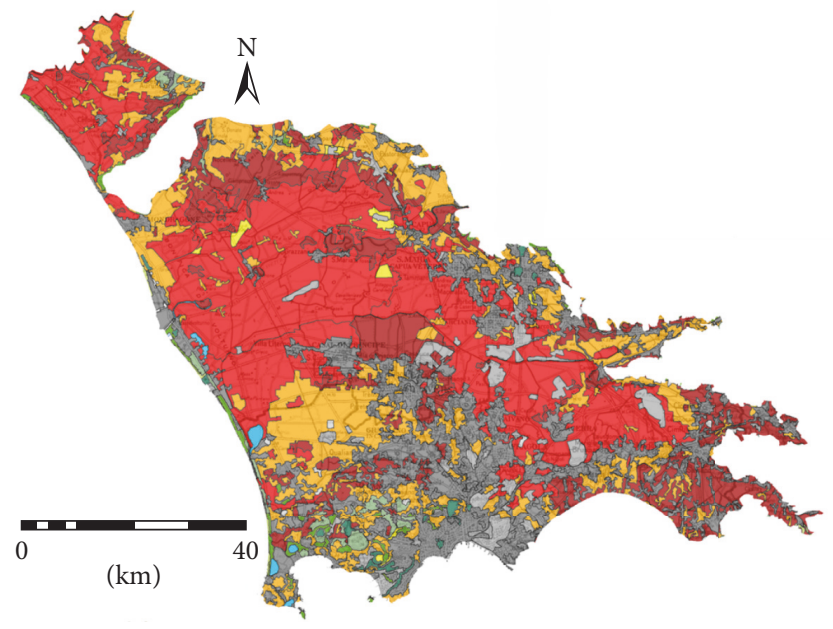

11 Urban fabric

12 Industrial, commercial and transport units

13 Mine, dump and construction sites

14 Artificial, non agricultural vegetated areas

21 Arable land

22 Permanent crops

23 Pastures

24 Heterogenoeus agricultural areas

31 Forests

32 Scrub and/or herbaceous vegetation associations

33 Open spaces with little or no vegetation

42 Maritime coastlands

51 Inland waters

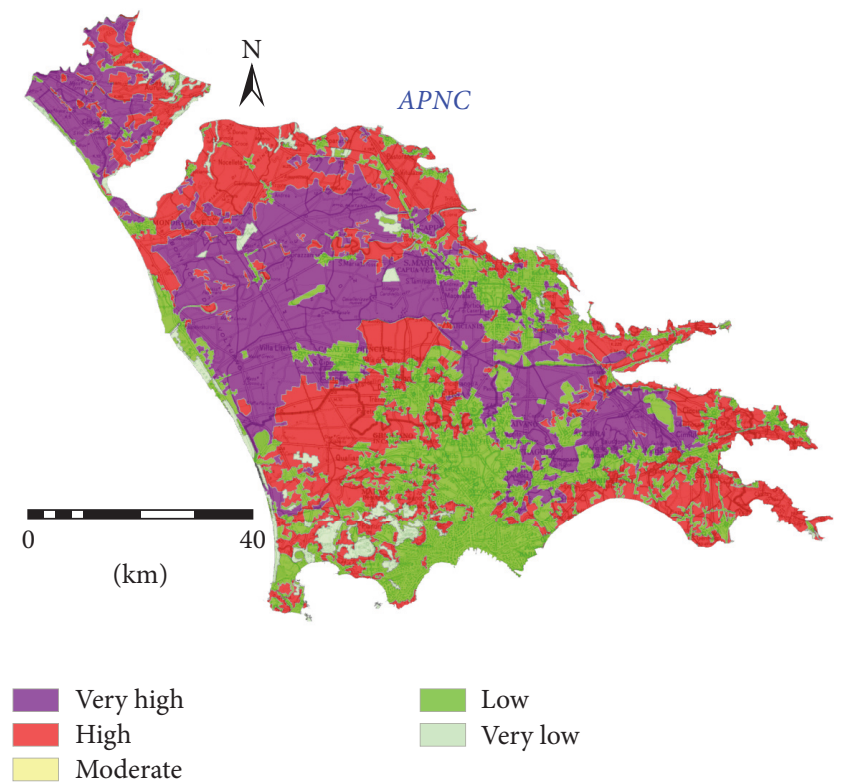

(a)

(b)
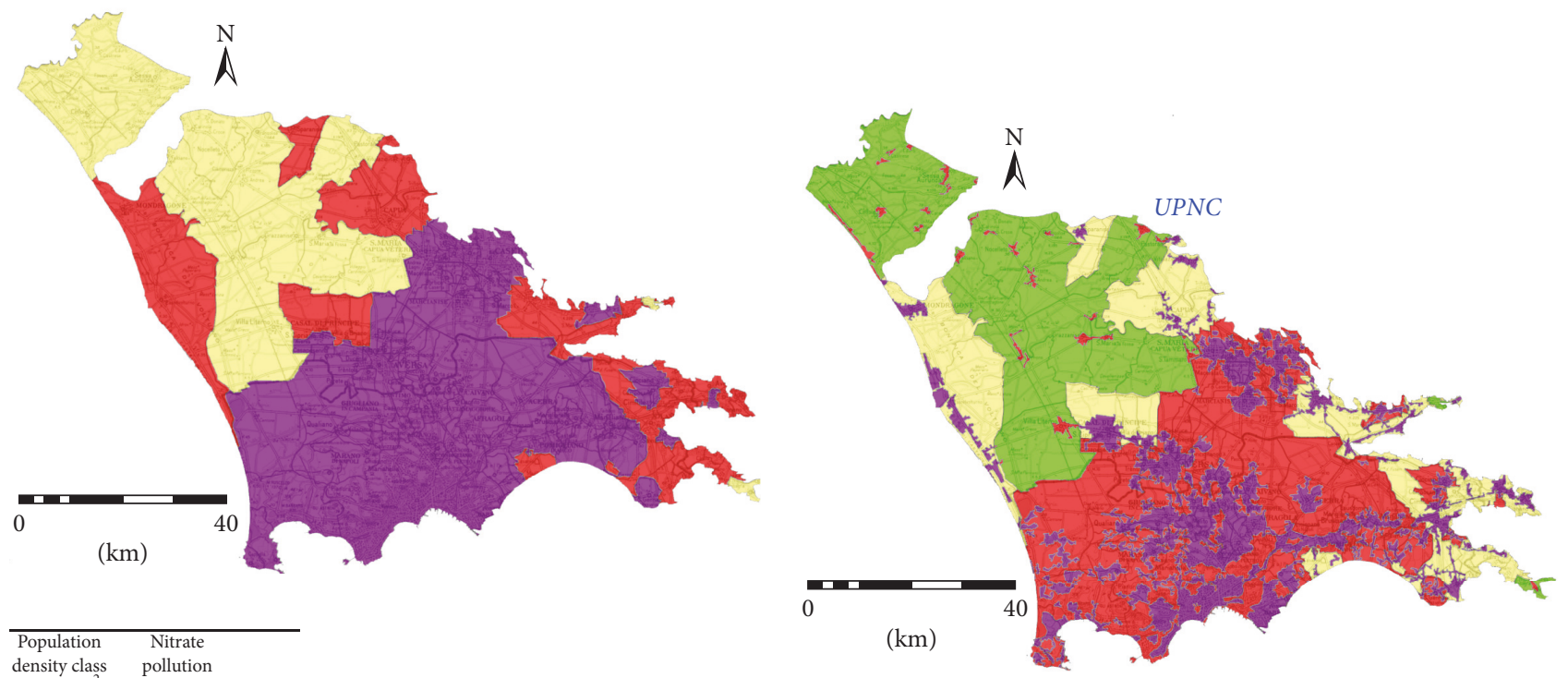

\begin{tabular}{lll}
\hline $\begin{array}{l}\text { Population } \\
\text { density class } \\
\left(\text { inhab } / \mathrm{km}^{2}\right)\end{array}$ & $\begin{array}{c}\text { Nitrate } \\
\text { pollution } \\
\text { potential }\end{array}$ & \\
\hline $25-250$ & Moderate & \\
$250-1000$ & High & \\
$>1000$ & Very high & \\
\hline
\end{tabular}

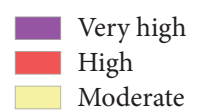

(c)

(d)

Figure 4: (a) Land use: Corine Land Cover, level 2, and (b) the derived Agricultural Potential Nitrate Contamination (APNC) map) (for the classification see Table 1); (c) population density and (d) the derived Urban Potential Nitrate Contamination (UPNC) map (for the classification see Table 2). 
TABle 4: Overlay matrix for the Potential Nitrate Contamination (PNC) map; APNC = Agricultural Potential Nitrate Contamination; UPNC $=$ Urban Potential Nitrate Contamination; PuPNC $=$ Periurban Potential Nitrate Contamination.

\begin{tabular}{|c|c|c|c|c|c|c|c|c|c|c|c|c|c|c|c|c|c|c|c|c|c|c|c|c|c|}
\hline \multirow{2}{*}{$\begin{array}{l}\mathrm{APNC} \rightarrow \\
\mathrm{UPNC} \rightarrow\end{array}$} & \multicolumn{5}{|c|}{ Very low } & \multicolumn{5}{|c|}{ Low } & \multicolumn{5}{|c|}{ Moderate } & \multicolumn{5}{|c|}{ High } & \multicolumn{5}{|c|}{ Very high } \\
\hline & $\mathrm{vl}$ & 1 & $\mathrm{~m}$ & $\mathrm{~h}$ & vh & $\mathrm{vl}$ & 1 & $\mathrm{~m}$ & $\mathrm{~h}$ & vh & $\mathrm{vl}$ & 1 & $\mathrm{~m}$ & $\mathrm{~h}$ & vh & $\mathrm{vl}$ & 1 & $\mathrm{~m}$ & $\mathrm{~h}$ & vh & 1 & 1 & $\mathrm{~m}$ & $\mathrm{~h}$ & $\mathrm{vh}$ \\
\hline PuPNC $\downarrow$ & & & & & & & & & & & & & & & & & & & & & & & & & \\
\hline $\mathrm{vl}$ & $\mathrm{vl}$ & $\mathrm{vl}$ & 1 & 1 & 1 & $\mathrm{vl}$ & 1 & 1 & 1 & $\mathrm{~m}$ & 1 & 1 & 1 & $\mathrm{~m}$ & $\mathrm{~m}$ & 1 & 1 & $\mathrm{~m}$ & $\mathrm{~m}$ & $\mathrm{~m}$ & 1 & $\mathrm{~m}$ & $\mathrm{~m}$ & $\mathrm{~m}$ & $\mathrm{~h}$ \\
\hline 1 & $\mathrm{vl}$ & 1 & 1 & 1 & $\mathrm{~m}$ & 1 & 1 & 1 & $\mathrm{~m}$ & $\mathrm{~m}$ & 1 & 1 & $\mathrm{~m}$ & $\mathrm{~m}$ & $\mathrm{~m}$ & 1 & $\mathrm{~m}$ & $\mathrm{~m}$ & $\mathrm{~m}$ & $\mathrm{~h}$ & $\mathrm{~m}$ & $\mathrm{~m}$ & $\mathrm{~m}$ & $\mathrm{~h}$ & $\mathrm{~h}$ \\
\hline $\mathrm{m}$ & 1 & 1 & 1 & $\mathrm{~m}$ & $\mathrm{~m}$ & 1 & 1 & $\mathrm{~m}$ & $\mathrm{~m}$ & $\mathrm{~m}$ & 1 & $\mathrm{~m}$ & $\mathrm{~m}$ & $\mathrm{~m}$ & $\mathrm{~h}$ & $\mathrm{~m}$ & $\mathrm{~m}$ & $\mathrm{~m}$ & $\mathrm{~h}$ & $\mathrm{~h}$ & $\mathrm{~m}$ & $\mathrm{~m}$ & $\mathrm{~h}$ & $\mathrm{~h}$ & $\mathrm{~h}$ \\
\hline $\mathrm{h}$ & 1 & 1 & $\mathrm{~m}$ & $\mathrm{~m}$ & $\mathrm{~m}$ & 1 & $\mathrm{~m}$ & $\mathrm{~m}$ & $\mathrm{~m}$ & $\mathrm{~h}$ & $\mathrm{~m}$ & $\mathrm{~m}$ & $\mathrm{~m}$ & $\mathrm{~h}$ & $\mathrm{~h}$ & $\mathrm{~m}$ & $\mathrm{~m}$ & $\mathrm{~h}$ & $\mathrm{~h}$ & $\mathrm{~h}$ & $\mathrm{~m}$ & $\mathrm{~h}$ & $\mathrm{~h}$ & $\mathrm{~h}$ & vh \\
\hline vh & 1 & $\mathrm{~m}$ & $\mathrm{~m}$ & $\mathrm{~m}$ & $\mathrm{~h}$ & $\mathrm{~m}$ & $\mathrm{~m}$ & $\mathrm{~m}$ & $\mathrm{~h}$ & $\mathrm{~h}$ & $\mathrm{~m}$ & $\mathrm{~m}$ & $\mathrm{~h}$ & $\mathrm{~h}$ & $\mathrm{~h}$ & $\mathrm{~m}$ & $\mathrm{~h}$ & $\mathrm{~h}$ & $\mathrm{~h}$ & vh & $\mathrm{h}$ & $\mathrm{h}$ & $\mathrm{h}$ & $\mathrm{vh}$ & vh \\
\hline
\end{tabular}

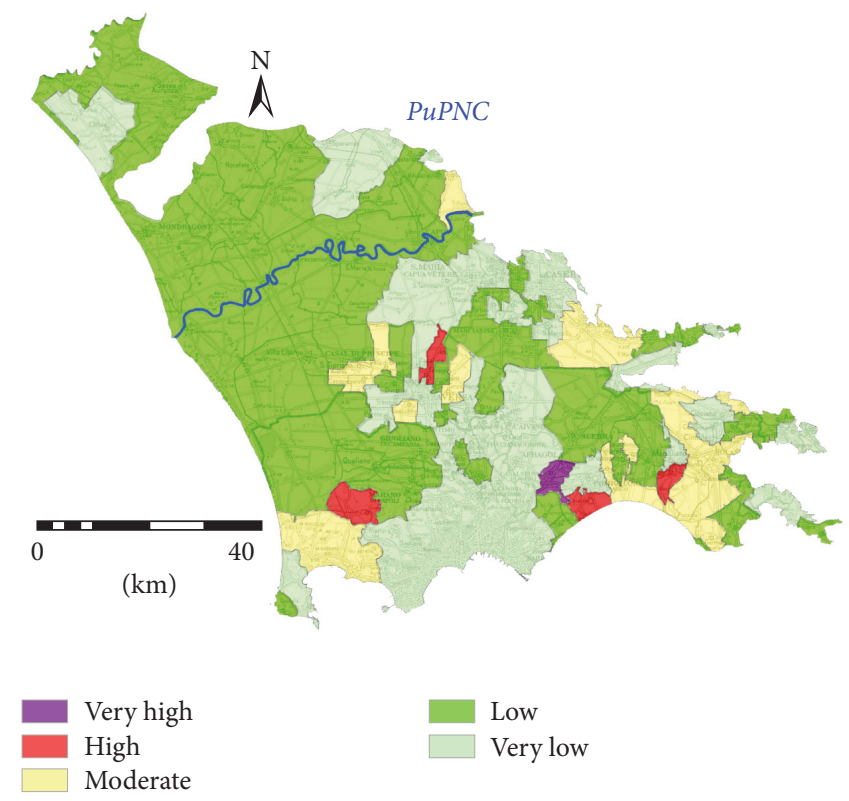

Figure 5: Periurban Potential Nitrate Contamination (PuPNC) map drawn up on the basis of the sewer system covering at municipal level.

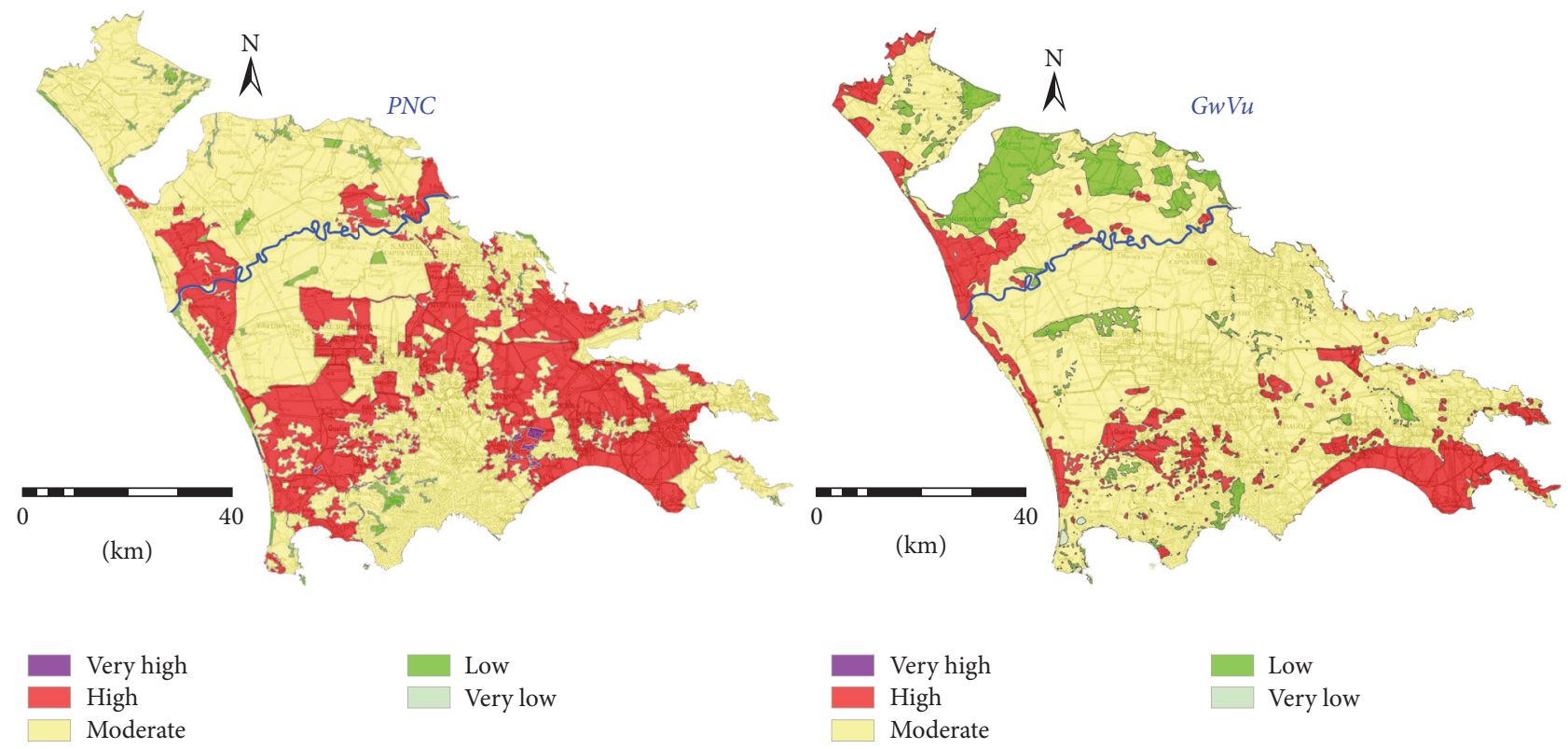

Figure 6: The Potential Nitrate Contamination (PNC) map drawn up on the basis of the overlay matrix of Table 3 and the groundwater contamination vulnerability $(\mathrm{GwVu})$ map assessed in previous studies [33-35] using the SINTACS method [36]. 


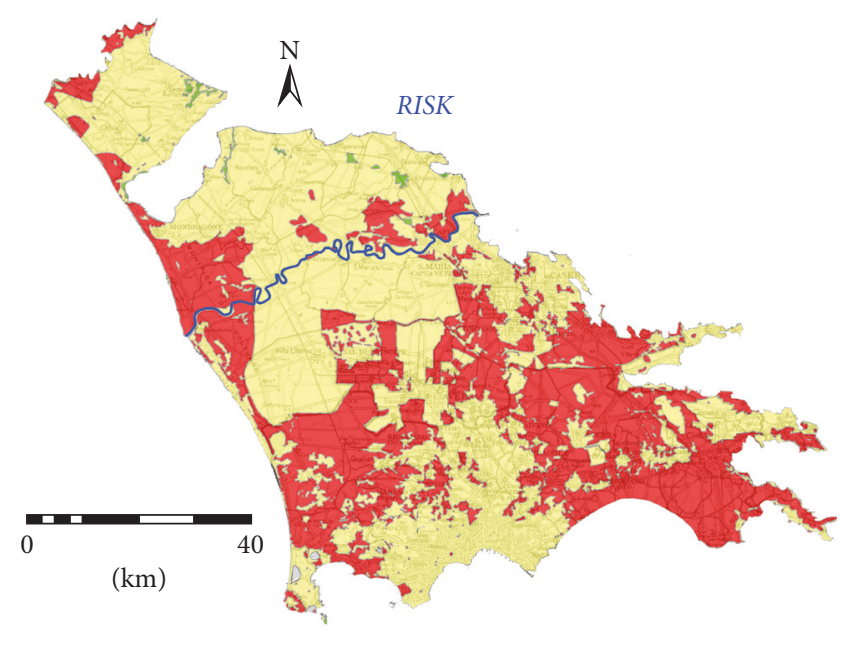

Susceptibility degree

High

Moderate

Low

Figure 7: The Groundwater Nitrate Contamination Susceptibility (RISK) map.

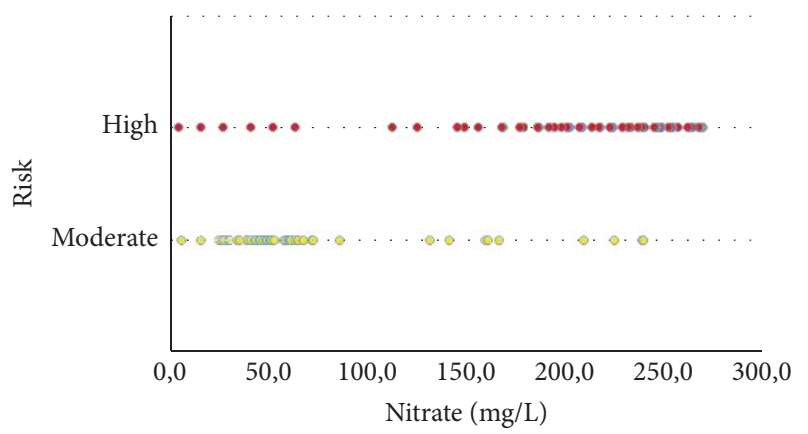

FIGURE 8: Correlation between the nitrate content (mg/L) measured in the groundwater monitoring wells of Figure 2 and the classes of the Groundwater Nitrate Contamination Susceptibility (RISK) map, excluding the area with negative redox conditions in the aquifer.

The potential agricultural nitrate contamination risk maps drawn up for two subsectors of the study area in Corniello et al. [40] and in Capri et al. [30], applying jointly the SINTACS vulnerability model [36] and the IPNOA hazard model [29], showed the same prevalence of moderate and high classes of risk. The main difference, especially in the area located north of the Volturno River, is the presence of wide areas at low risk. In this comparison it should be remembered that the method applied in the previous papers only considered the risk of contamination of agricultural origin and it is much more detailed, requiring a great deal of data, difficult to find at regional scale.

Finally, the advantage of the method here proposed, compared to the other methods proposed in the last five years $[5,20,22,25,27,28,32]$, is chiefly in his suitability for application in areas with few data or at large scale.

\section{Conclusions}

Vulnerability maps have been used during the last 40 years to determine the intrinsic vulnerability and thus are exclusively based on the hydrogeological characteristics of the aquifers. The method here proposed determines a susceptibility/risk of groundwater to nitrate contamination, and it differs from vulnerability models because it includes the evaluation of the contamination potential.

Indeed, the pollution susceptibility map of the study area has been obtained by combining two basic thematic maps: the Potential Nitrate Contamination (PNC) map and the groundwater contamination vulnerability $(\mathrm{GwVu})$ map. The Potential Nitrate Contamination is considered as deriving from three sources: agricultural, urban, and periurban. The criterion for the linkages of the different GIS layers, proposed in this paper, is very simple, corresponding to an algebraic combination.

The proposed method, applied in a large flat area of southern Italy, with high $\mathrm{NO}_{3}$ content in the aquifers and very high human pressure (in terms of population density and intensive agriculture), was validated using the nitrate distribution map, deriving from measures in wells, showing a good agreement between the nitrate contamination and the pollution susceptibility map. The differences can be easily explained on the basis of hydrogeological and hydrogeochemical considerations. Future applications in different environments will be able to confirm the validity of this method.

The procedures used to evaluate the susceptibility are very easy to use and they allow a correct management of agricultural areas: areas indicated at high vulnerability could be limited for some land use types while intensive agriculture may be directed to those areas of low vulnerability.

Finally, the main advantages of the methodology proposed in this study for nitrate groundwater susceptibility assessment are the possibility of being applied at large scale (e.g., regional); the easy availability and the flexibility in the starting data, often coming from different sources; the simplicity and the clearness in the application of the method, also by environmental technicians and not only by scientists; the reliability (in terms of correspondence with the $\mathrm{NO}_{3}$ measured values) and the scientific rigour of the susceptibility map produced.

\section{Conflicts of Interest}

The author declares that they have no conflicts of interest.

\section{Acknowledgments}

The author is very grateful to the University Language Centre of the Federico II University for the careful revision of the English language.

\section{References}

[1] G. Tredoux, P. Engelbrecht, and S. Israel, "Nitrate in groundwater: Why is it a hazard and how to control it?" Report to the 
Water Research Commission by CSIR, Natural Resources and the Environment, Stellenbosch, 2009.

[2] World Health Organization, Guidelines for Drinking Water Quality, World Health Organization (WHO), Geneva, Switzerland, 2011.

[3] X. Su, H. Wang, and Y. Zhang, "Health Risk Assessment of Nitrate Contamination in Groundwater: A Case Study of an Agricultural Area in Northeast China," Water Resources Management, vol. 27, no. 8, pp. 3025-3034, 2013.

[4] K. R. Burow, B. T. Nolan, M. G. Rupert, and N. M. Dubrovsky, "Nitrate in groundwater of the United States, 1991-2003," Environmental Science \& Technology, vol. 44, no. 13, pp. 4988-4997, 2010.

[5] P. Kumar, P. K. Thakur, B. K. Bansod, and S. K. Debnath, "Multicriteria evaluation of hydro-geological and anthropogenic parameters for the groundwater vulnerability assessment," Environmental Modeling \& Assessment, vol. 189, no. 11, article no. 564, 2017.

[6] P. Kumar, B. K. S. Bansod, S. K. Debnath, P. K. Thakur, and C. Ghanshyam, "Index-based groundwater vulnerability mapping models using hydrogeological settings: A critical evaluation," Environmental Impact Assessment Review, vol. 51, pp. 38-49, 2015.

[7] P. Wachniew, A. J. Zurek, C. Stumpp et al., "Toward operational methods for the assessment of intrinsic groundwater vulnerability: A review," Critical Reviews in Environmental Science and Technology, vol. 46, no. 9, pp. 827-884, 2016.

[8] D. Ducci, "GIS techniques for mapping groundwater contamination risk," Natural Hazards, vol. 20, no. 2-3, pp. 279-294, 1999.

[9] A. Zaporozec, Groundwater contamination inventory: a methodological guide. IHP-VI, Series on groundwater, UNESCO, Paris, France, 2004.

[10] S. Saidi, S. Bouri, H. Ben Dhia, and B. Anselme, "Assessment of groundwater risk using intrinsic vulnerability and hazard mapping: Application to Souassi aquifer, Tunisian Sahel," Agricultural Water Management, vol. 98, no. 10, pp. 1671-1682, 2011.

[11] M. Kerr-Upal, T. Van Seters, G. Whitehead, J. Price, and M. Stone, "Assessing the risk of groundwater nitrate contamination in the region of waterloo, ontario," Canadian Water Resources Journal, vol. 24, no. 3, pp. 225-233, 1999.

[12] J. L. Baker and J. M. Laflen, "Water quality consequences of conservation tillage.," Journal of Soil \& Water Conservation, vol. 38, no. 3, pp. 186-193, 1983.

[13] G. Passarella, M. Vurro, V. D’Agostino, G. Giuliano, and M. J. Barcelona, "A probabilistic methodology to assess the risk of groundwater quality degradation," Environmental Modeling \& Assessment, vol. 79, no. 1, pp. 57-74, 2002.

[14] N. Diodato, L. Esposito, G. Bellocchi, L. Vernacchia, F. Fiorillo, and F. M. Guadagno, "Assessment of the Spatial Uncertainty of Nitrates in the Aquifers of the Campania Plain (Italy)," American Journal of Climate Change, vol. 02, no. 02, pp. 128-137, 2013.

[15] V. G. Aschonitis, M. Mastrocicco, N. Colombani et al., "Assessment of the intrinsic vulnerability of agricultural land to water and nitrogen losses via deterministic approach and regression analysis," Water, Air, \& Soil Pollution, vol. 223, no. 4, pp. 16051614, 2012.

[16] T. Y. Stigter, L. Ribeiro, and A. M. M. C. Dill, "Evaluation of an intrinsic and a specific vulnerability assessment method in comparison with groundwater salinisation and nitrate contamination levels in two agricultural regions in the south of Portugal," Hydrogeology Journal, vol. 14, no. 1-2, pp. 79-99, 2006.
[17] M. Metni, M. El-Fadel, S. Sadek, R. Kayal, and D. L. El Khoury, "Groundwater resources in Lebanon: A vulnerability assessment," International Journal of Water Resources Development, vol. 20, no. 4, pp. 475-491, 2004.

[18] H. Huan, J. Wang, and Y. Teng, "Assessment and validation of groundwater vulnerability to nitrate based on a modified DRASTIC model: A case study in Jilin City of northeast China," Science of the Total Environment, vol. 440, pp. 14-23, 2012.

[19] A. Neshat, B. Pradhan, and M. Dadras, "Groundwater vulnerability assessment using an improved DRASTIC method in GIS," Resources, Conservation \& Recycling, vol. 86, pp. 74-86, 2014.

[20] A. Neshat and B. Pradhan, "An integrated DRASTIC model using frequency ratio and two new hybrid methods for groundwater vulnerability assessment," Natural Hazards, vol. 76, no. 1, pp. 543-563, 2015.

[21] A. Sorichetta, C. Ballabio, M. Masetti, G. R. Robinson, and S. Sterlacchini, "A comparison of data-driven groundwater vulnerability assessment methods," Groundwater, vol. 51, no. 6, pp. 866-879, 2013.

[22] M. Bonfanti, D. Ducci, M. Masetti, M. Sellerino, and S. Stevenazzi, "Using statistical analyses for improving rating methods for groundwater vulnerability in contamination maps," Environmental Earth Sciences, vol. 75, no. 12, article no. 1003, 2016.

[23] J. Uhan, G. Vižintin, and J. Pezdič, "Groundwater nitrate vulnerability assessment in alluvial aquifer using process-based models and weights-of-evidence method: Lower Savinja Valley case study (Slovenia)," Environmental Earth Sciences, vol. 64, no. 1, pp. 97-105, 2011.

[24] T. S. Narany, M. F. Ramli, A. Z. Aris, W. N. A. Sulaiman, and K. Fakharian, "Spatial assessment of groundwater quality monitoring wells using indicator kriging and risk mapping, Amol-Babol Plain, Iran," Water (Switzerland), vol. 6, no. 1, pp. 68-85, 2014.

[25] S.-K. Chen, C.-S. Jang, and Y.-H. Peng, "Developing a probability-based model of aquifer vulnerability in an agricultural region," Journal of Hydrology, vol. 486, pp. 494-504, 2013.

[26] C. Piccini, A. Marchetti, R. Farina, and R. Francaviglia, "Application of indicator kriging to evaluate the probability of exceeding nitrate contamination thresholds," International Journal of Environmental Research, vol. 6, no. 4, pp. 853-862, 2012.

[27] M. Chica-Olmo, E. Pardo-Igúzquiza, A. Luque-Espinar, V. Rodríguez-Galiano, and L. Chica-Rivas, "Quantitative Risk Management of Groundwater Contamination by Nitrates Using Indicator Geostatistics," in Mathematics of Planet Earth, Lecture Notes in Earth System Sciences, pp. 533-536, Springer Berlin Heidelberg, Berlin, Heidelberg, 2014.

[28] E. Fijani, A. A. Nadiri, A. Asghari Moghaddam, F. T.-C. Tsai, and B. Dixon, "Optimization of drastic method by supervised committee machine artificial intelligence to assess groundwater vulnerability for maragheh-bonab plain aquifer, Iran," Journal of Hydrology, vol. 503, pp. 89-100, 2013.

[29] L. Padovani and M. Trevisan, I nitrati di origine agricola nelle acque sotterranee. Un indice parametrico per l'individuazione di aree vulnerabili, Quad. e tecn. Di Protez. Ambient., Bologna, Italy, 2002.

[30] E. Capri, M. Civita, A. Corniello et al., "Assessment of nitrate contamination risk: The Italian experience," Journal of Geochemical Exploration, vol. 102, no. 2, pp. 71-86, 2009.

[31] D. Ducci, G. De Masi, and G. Delli Priscoli, "Contamination risk of the Alburni Karst System (Southern Italy)," Engineering Geology, vol. 99, no. 3-4, pp. 109-120, 2008. 
[32] A. Pisciotta, G. Cusimano, and R. Favara, "Groundwater nitrate risk assessment using intrinsic vulnerability methods: A comparative study of environmental impact by intensive farming in the Mediterranean region of Sicily, Italy," Journal of Geochemical Exploration, vol. 156, pp. 89-100, 2015.

[33] D. Ducci, A. Corniello, and M. Sellerino, "Hydrostratigraphical setting and groundwater quality status in alluvial aquifers: the low Garigliano River Basin (Southern Italy), case study," Groundwater Quality Sustainability, vol. 1, pp. 197-203, 2010.

[34] A. Corniello and D. Ducci, "Hydrogeochemical characterization of the main aquifer of the "Litorale Domizio-Agro Aversano NIPS” (Campania - southern Italy)," Journal of Geochemical Exploration, vol. 137, pp. 1-10, 2014.

[35] D. Ducci and M. Sellerino, "Vulnerability mapping of groundwater contamination based on 3D lithostratigraphical models of porous aquifers," Science of the Total Environment, vol. 447, pp. 315-322, 2013.

[36] M. Civita and M. De Maio, SINTACS R5 - Valutazione e cartografia automatica della vulnerabilità degli acquiferi all'inquinamento con il sistema parametrico, Pitagora, Bologna, Italy, 2000.

[37] G. Busico, E. Cuoco, N. Kazakis et al., "Multivariate statistical analysis to characterize/discriminate between anthropogenic and geogenic trace elements occurrence in the Campania Plain, Southern Italy," Environmental Pollution, vol. 234, pp. 260-269, 2018.

[38] D. Ducci, H. Massone, and E. Bocanegra, "Linkage of social and natural variables to nitrate groundwater contamination in multiple-use areas: Naples (Italy) and Mar del Plata (Argentina)," in Proceedings of the XXXV IAH Congress "Groundwater and Ecosystems", p. 10, 2007.

[39] P. Crouzet, "Calculation of nutrient surpluses from agricultural sources - Statistics spatialisation by means of CORINE land cover - Application to the case of nitrogen. European Environment Agency," Tech. Rep., Copenhagen, 2000.

[40] A. Corniello, D. Ducci, and G. Ruggieri, "Areal identification of groundwater nitrate contamination sources in periurban areas," Journal of Soils and Sediments, vol. 7, no. 3, pp. 159-166, 2007. 

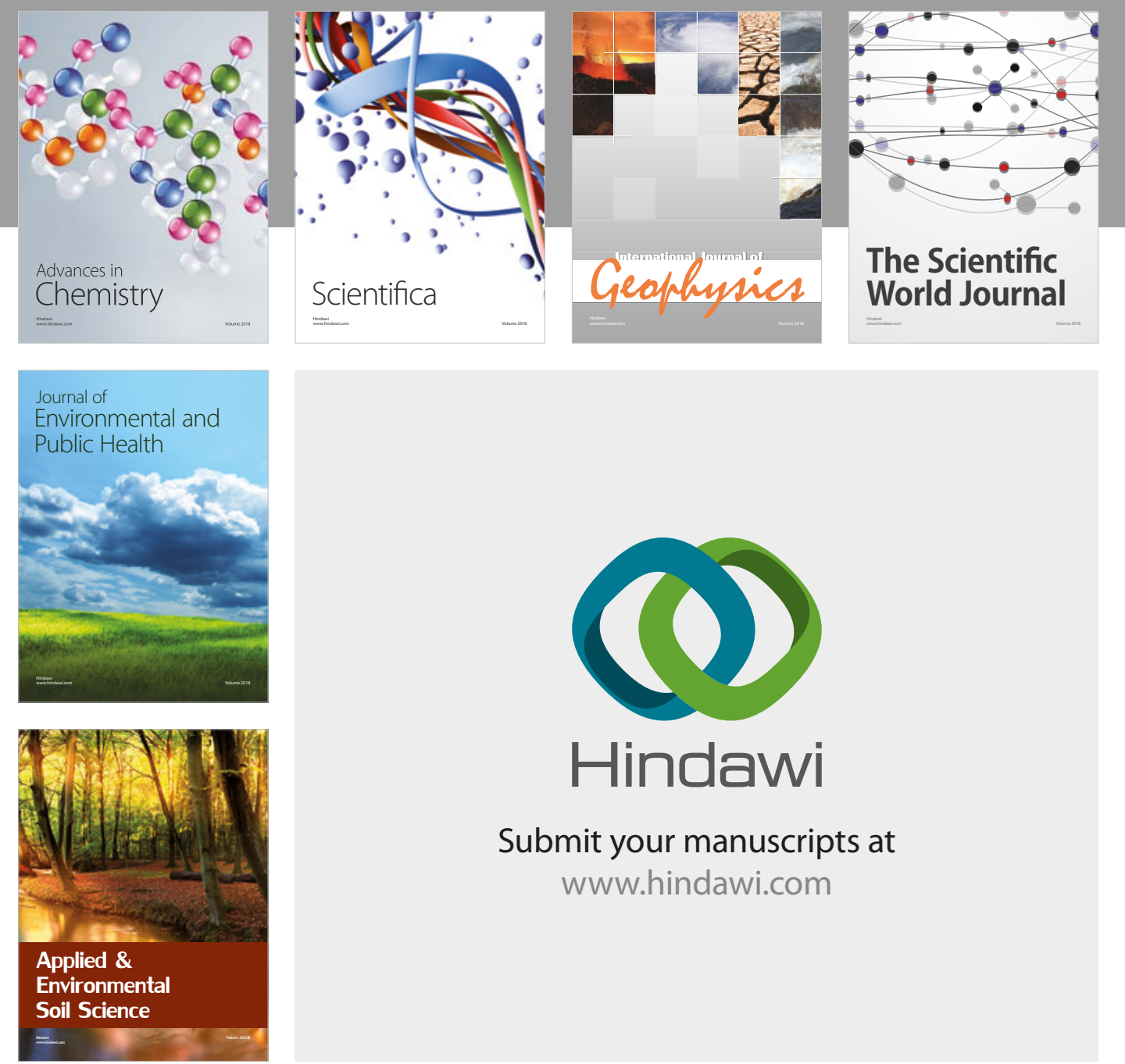

The Scientific

\section{World Journal}
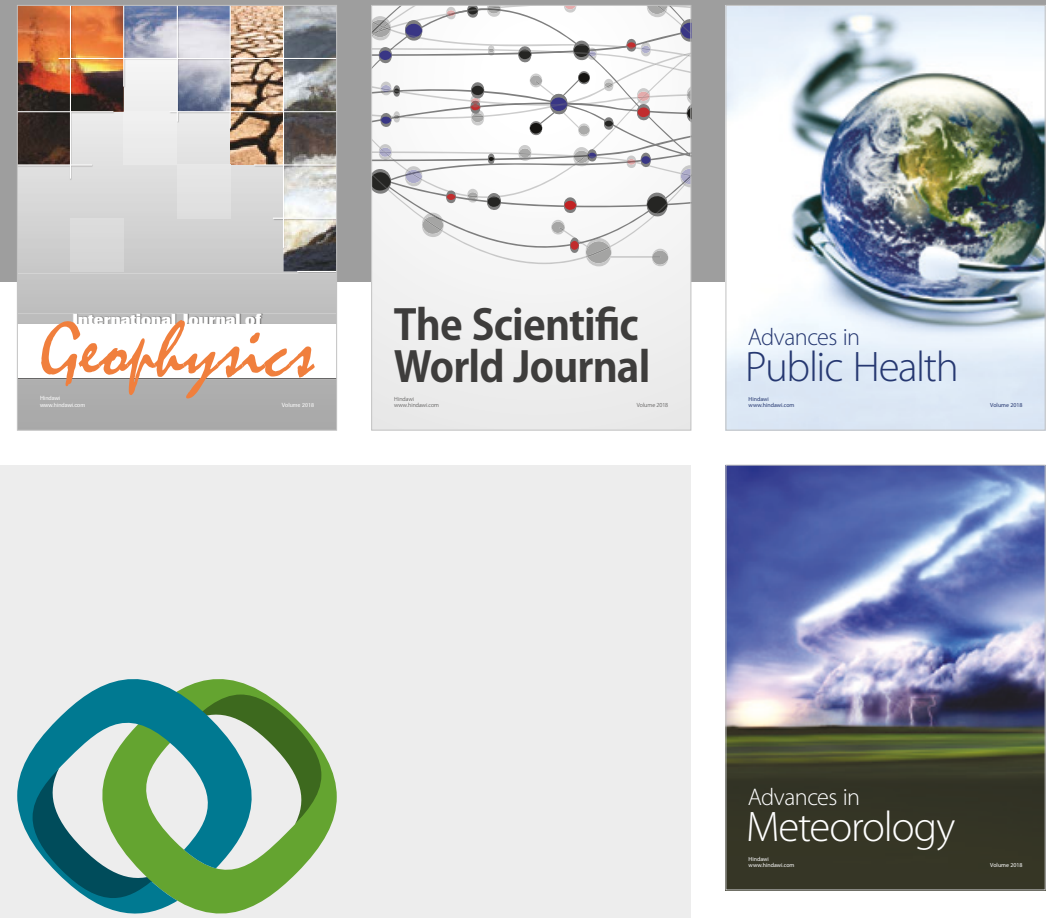

Advan

Public Health

\section{Hindawi}

Submit your manuscripts at

www.hindawi.com
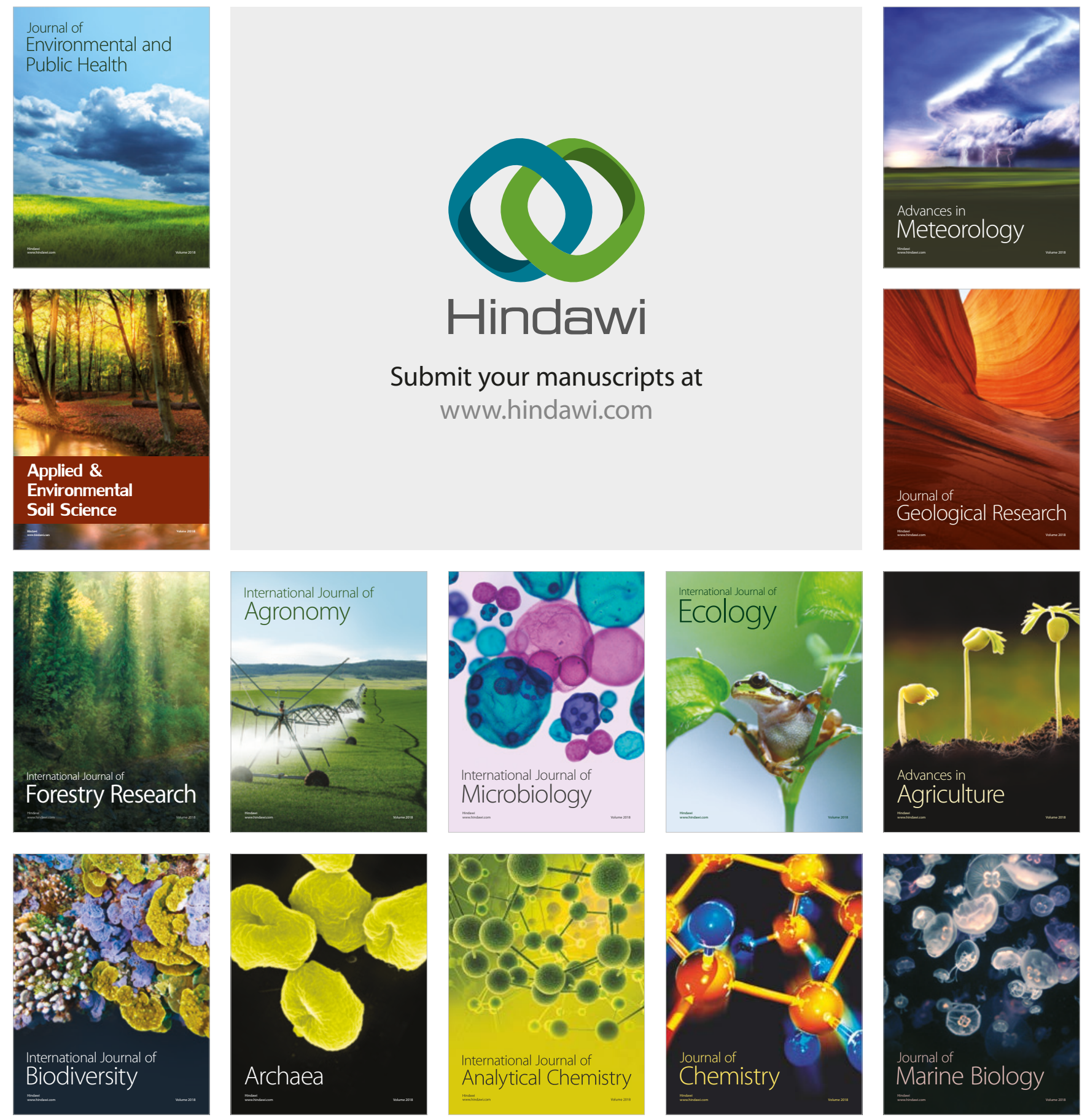